\title{
The Adipocyte and Adaptive Immunity
}

\author{
Jianfeng Song ${ }^{1,2}$ and Tuo Deng ${ }^{1,2,3 *}$ \\ ${ }^{1}$ National Clinical Research Center for Metabolic Diseases, and Department of Metabolism and Endocrinology, The Second \\ Xiangya Hospital of Central South University, Changsha, China, ${ }^{2}$ Key Laboratory of Diabetes Immunology, Ministry of \\ Education, and Metabolic Syndrome Research Center, The Second Xiangya Hospital of Central South University, \\ Changsha, China, ${ }^{3}$ Clinical Immunology Center, The Second Xiangya Hospital of Central South University, Changsha, China
}

OPEN ACCESS

Edited by:

Willa Ann Hsueh,

The Ohio State University,

United States

Reviewed by:

David Bradley,

The Ohio State University,

United States

Aimin Xu,

The University of Hong Kong,

Hong Kong

*Correspondence:

Tuo Deng

dengtuo@csu.edu.cn

Specialty section:

This article was submitted to Immunological Tolerance and Regulation,

a section of the journal

Frontiers in Immunology

Received: 09 August 2020 Accepted: 27 October 2020

Published: 27 November 2020

Citation:

Song J and Deng T (2020) The Adipocyte and Adaptive Immunity.

Front. Immunol. 11:593058. doi: 10.3389/fimmu.2020.593058
Not only do Adipocytes have energy storage and endocrine functions, but they also play an immunological role. Adipocytes are involved in adaptive immunity to mediate the pathological processes of a variety of chronic inflammatory diseases and autoimmune syndromes. The adaptive immune response consists of $\mathrm{T}$ cell-mediated cellular immunity and B cell-mediated humoral immunity. Obese adipocytes overexpress MHC class II molecules and costimulators to act as antigen-presenting cells (APCs) and promote the activation of $\mathrm{CD} 4^{+} T$ cells. In addition, various adipokines secreted by adipocytes regulate the proliferation and differentiation of $\mathrm{T}$ cells. Adipokines are also involved in B cell generation, development, activation, and antibody production. Therefore, adipocytes play an important role in B cell-mediated adaptive immunity. This review describes how adipocytes participate in adaptive immunity from the perspective of $T$ cells and B cells, and discusses their role in the pathogenesis of various diseases.

Keywords: adipocyte, adaptive immunity, adipokine, T cell, B cell

\section{INTRODUCTION}

Adaptive immunity is characterized by specificity, immunological memory, and self/nonself recognition (1). The function of the adaptive immune system is to recognize, remember and destroy invading pathogens through their antigens, and relieve pathogen-associated toxicities. There are two main mechanisms in the adaptive immune system-humoral immunity and cellular immunity, which are mediated by antibodies and cells respectively. The $\mathrm{T}$ and $\mathrm{B}$ cells are the major components of adaptive immunity. T cells play a large role in the cellular immune response, while B cells are intimately involved in the humoral immune response.

Adipocytes are the main constituent cells of adipose tissue. Their main function is to store energy in the form of lipid droplets when there is excess energy and to supply energy when the body demands it. In addition to their main functions, adipocytes have endocrine functions and can secrete a variety of adipokines such as leptin, adiponectin, and resistin (2-4). Recently, an increasing number of studies have shown that adipocytes have immunological functions capable of recruiting and activating immune cells. The adipocyte was reported as an antigen-presenting cell (APC) which expresses CD1d and MHC class I and II molecules. Several studies have shown that adipocytes highly express CD1d, which presents lipid antigens to invariant natural killer T (iNKT) cells and stimulates the activation of iNKT cells (5-7). Moreover, like other nucleated cells, adipocytes express MHC class I molecules. However, there is no clear evidence that adipocytes interact directly 
with $\mathrm{CD}^{+} \mathrm{T}$ cells through antigen:MHCI complex. In our recent research, we observed that adipocytes express MHC class II molecules and co-stimulatory molecules CD80/CD86, and that their expression significantly increases in response to high fat diet (HFD) challenges (8). Adipocytes can directly activate CD4 ${ }^{+}$ $\mathrm{T}$ cells through antigen:MHCII complex in a contact-dependent manner. Simultaneously, adipocytes secrete various cytokines including leptin, resistin, TNF- $\alpha$ and IL- 6 to regulate the differentiation and function of $\mathrm{T}$ and $\mathrm{B}$ lymphocytes.

Adipocytes can regulate adaptive immunity, which is involved with various metabolic diseases. Since there have been many reports on the regulation of metabolic diseases through adaptive immunity (9-11), we focus on how adipocytes regulate adaptive immunity in this review. First, we introduce adipocytes as APCs to participate in $\mathrm{T}$ cell-mediated adaptive immune response. Next, we summarize various cytokines produced by adipocytes that regulate the survival, activation and differentiation of B cells. Adaptive immunity mediates the pathological processes of a variety of chronic inflammatory diseases, autoimmune syndromes and cancers. Thus, we discuss the role of adipocytes in adaptive immunity in the context of inflammatory and autoimmune diseases.

\section{THE ROLE OF ADIPOCYTES IN T CELL- MEDIATED ADAPTIVE IMMUNITY}

The activation and differentiation of $\mathrm{T}$ cells require three signals: antigen presentation, costimulation, and cytokine stimulation. APCs are required for $\mathrm{T}$ cell activation. They can process and present antigens to $\mathrm{T}$ cells in the form of antigen peptide:MHC molecular complexes, which are recognized by TCR on T cells to provide the first signal for $\mathrm{T}$ cell activation. Moreover, APCs highly express co-stimulatory molecules and pair with the corresponding receptor or ligand molecules on the surface of $\mathrm{T}$ cells, constituting the second signal for $\mathrm{T}$ cell activation. After $\mathrm{T}$ cells are fully activated, the further proliferation and differentiation of $\mathrm{T}$ cells depends on a variety of cytokines, including IL-2, IL-4, IL-6, IL-10, IL-12, and IFN- $\gamma$. In this section, we will describe how adipocytes act as APCs to provide all three signals for $\mathrm{T}$ cells activation and differentiation.

\section{Adipocyte-Mediated Antigen Presentation}

Adipocytes express both MHC classes I and II molecules. MHCI molecules are expressed in all nucleated cells and mediate CD8 ${ }^{+}$ $\mathrm{T}$ cell activation, while $\mathrm{MHCII}$ molecules are restricted to antigen-presenting cells (APCs) and induce $\mathrm{CD}^{+} \mathrm{T}$ cell activation by antigen presentation. APCs are divided into professional APCs and non-professional APCs. The former includes dendritic cells (DC), monocytes/macrophages, and B lymphocytes, and the latter comprises endothelial cells, epithelial cells and fibroblasts (12). In our previous studies, we found that adipocytes also express MHCII molecules, and that their levels are significantly increased in adipocytes of HFD fed mice (8). In contrast, MHCI-related genes in adipocytes remain unchanged during obesity.
Adipocyte MHCII begins to increase at 2 weeks of HFD, and the expression of pro-inflammatory Th1 marker genes Tbx 21 and Ifng in adipose tissue resident T cells (ART) increase at 2-3 weeks following HFD, suggesting that adipocyte MHCII may mediate Th1 cell activation and trigger obesity-induced adipose inflammation. In vitro adipocyte-T cell co-culture experiments show that the activation of T cells by adipocytes is dependent on direct contact between adipocytes and T cells and the MHCII expression in adipocytes (8). Large adipocytes (diameter $>25$ $\mu \mathrm{m})$ express higher levels of MHCII than small adipocytes (diameter $<25 \mu \mathrm{m}$ ) in both ND (normal diet)- and HFD-fed mice. In obesity, large adipocytes are accumulated in adipose tissues and they overexpress MHCII molecules. These hypertrophic adipocytes can function as APCs to activate $\mathrm{CD}^{+}$ART and instigate adipose tissue inflammation, which could cause many obesity-related medical complications (13). Adipocyte-specific MHCII deficient $\left(\mathrm{aMHCII}^{-/}\right)$mice are significantly more sensitive to insulin and glucose tolerant than their wild type (WT) littermates when fed with HFD (14). In addition, adipocytes of $\mathrm{HFD}$-fed $\mathrm{aMHCII}^{-/}$mice exhibit reduced capacity to activate $\mathrm{CD} 4^{+} \mathrm{T}$ cells, as manifested by attenuated secretion of IFN- $\gamma$, a major Th1 cytokine (14). Furthermore, adipocyte MHCII has an indirect effect on Tregs in visceral adipose tissue (VAT). aMHCII ${ }^{-/-}$mice show increased Treg abundance in VAT, compared with WT mice under HFD. In vitro experiments show that IFN- $\gamma$ dosedependently inhibits Treg differentiation (14). Thus, in the HFD-fed $\mathrm{aMHCII}^{-/-}$mouse model, the drop of IFN- $\gamma$ may explain the increase of Tregs in VAT. Given that VAT Treg is a negative regulator of adipose inflammation and insulin resistance (15-17), the improved adipose inflammation and insulin resistance in $\mathrm{HFD}$-fed $\mathrm{aMHCII}^{-/-}$mice may result from the increase of Tregs in VAT. Indeed, the preserved insulin sensitivity of $\mathrm{HFD}$-fed $\mathrm{aMHCII}^{-/-}$mice is attenuated by ablation of Tregs in adipose tissue (14). These results indicate that adipocyte MHCII can promote adipose inflammation and insulin resistance. Consistently, adrenomedullin 2 improves adipose insulin resistance by inhibiting the adipocyte MHCII expression in the early stage of obesity (18). HFD-fed adipocyte HIF- $1 \alpha$ KO mice show decreased expression of MHCII genes, and can protect themselves from obesity-induced adipose inflammation (19). In summary, the adipocyte can function as APCs to induce $\mathrm{CD}^{+} \mathrm{T}$ cell activation and polarization in MHCII and antigen dependent pathway.

Current research on adipocyte MHCII antigen presentation and co-stimulation focuses on obesity and type 2 diabetes (T2D). Therefore, the metabolic diseases we have discussed in this review are obesity and T2D. Since adipocyte-mediated antigen presentation promotes adipose inflammation, which is strongly associated with a variety of metabolic diseases, including nonalcoholic fatty liver disease (NAFLD), atherosclerosis, heart disease, etc., adipocyte-mediated antigen presentation may contribute to these metabolic diseases indirectly.

\section{Co-Stimulatory Molecule in Adipocyte}

TCR recognition of antigen peptide/MHCII provides the primary signal for $\mathrm{CD}^{+} \mathrm{T}$ cell activation, while the full 
activation of $\mathrm{CD}^{+} \mathrm{T}$ cells requires the costimulation signal. Costimulatory molecules on the surface of T cells and APCs bind to each other in a receptor-ligand pairing manner. Costimulatory molecules expressed by $\mathrm{T}$ cells interacts with its ligands or receptors on the membrane of APCs, resulting in the activation of these cells and thus triggering immune response (20).

Recent studies have reported the role of $\mathrm{T}$ cell costimulators in HFD-induced obesity (21), but the contribution of adipocytes in T cell costimulation is still unclear. CD40 (22), CD80 (B7-1), CD86 $(B 7-2)(8,23)$ and $\operatorname{HVEM}(24,25)$ are induced in adipocytes of obese human or mice, and may costimulate adipose resident $\mathrm{T}$ cells (ARTs) in obesity. However, studies show that both CD40 knockout mice and CD80/CD86 double knockout mice under HFD feeding exhibit exacerbated adipose tissue inflammation and metabolic disorders. To understand these unexpected results, investigators explored the involvement of other factors that can also influence the phenotype of these mice. After binding with CD40L, CD40 triggers the recruitment of adaptor proteins, the TNFRassociated factors (TRAFs), to activate intracellular signaling (26). The cytoplasmic region of CD40 contains a proximal binding site for TRAF6 and a distal binding site for TRAF2/3/ 5. Mice that are deficient in CD40-TRAF2/3/5 signaling in $\mathrm{MHCII}^{+}$cells display a similar phenotype as $\mathrm{CD} 40^{-1-}$ mice under HFD, whereas mice with disrupted CD40-TRAF6 signaling in $\mathrm{MHCII}^{+}$cells are protected against obesityinduced metabolic dysfunction (27). CD40-TRAF2/3/5 and CD40-TRAF6 signaling have opposite effects in obesity-related metabolic disorders. This may explain the unexpected phenotype of $\mathrm{CD} 40^{-/-}$mice. In addition, CD80/CD86 double knockout mice have congenital defects in the development of Tregs, which may explain the aggravated adipose inflammation in these mice. Indeed, using antibodies to block both CD80 and CD86 can alleviate adipose inflammation, insulin resistance and fatty liver of diet-induced obese mice $(23,28)$. Another costimulatory receptor-ligand pair, HVEM-LIGHT, is also involved in the ART activation of DIO mice. LIGHT is expressed in both activated and resting $\mathrm{T}$ cells in mice (29). LIGHT binds to HVEM on adipocyte, and promotes the secretion of proinflammatory cytokines and chemokines in adipocytes by activating the NF-kB signaling pathway in human and mice $(30,31)$, thereby inducing the recruitment of $\mathrm{T}$ cells and macrophages in adipose tissue. Both HVEM genetical deletion and treatment of HVEM blocking antibodies in HFD-fed mice ameliorates obesity-induced adipose tissue inflammation and metabolic deterioration $(24,32)$.

These studies have suggested that $\mathrm{T}$ cell costimulatory molecules may be involved in the obesity-induced activation of ART and the development of adipose tissue inflammation. However, it is still uncertain whether adipocytes provide the $\mathrm{T}$ cell costimulatory signal to activate ARTs during obesity, because no studies have used adipocyte-specific costimulator knockout mice to confirm the function of adipocytes in $\mathrm{T}$ cell costimulation. Moreover, several costimulatory molecules have been linked to obesity-induced adipose inflammation and insulin resistance, but it is still unclear which costimulator plays the central role. Further studies are warranted to address these unanswered questions.

\section{Adipokines That Regulate Activation and Polarization of $\mathrm{T}$ Cell}

A variety of cytokines secreted by adipocytes can regulate the activation and differentiation of $\mathrm{T}$ cells and $\mathrm{B}$ cells, and participate in various metabolic and non-metabolic diseases. Since the topic of how adipokines contribute to metabolic diseases has been extensively described in many reviews (3336), in this review, we focus on non-metabolic diseases.

\section{Leptin}

Leptin is basically a pro-inflammatory adipokine that directly or indirectly regulates $\mathrm{T}$ cells proliferation and differentiation (Table 1). As early as 1998, Lord et al. found that leptin promotes the proliferation of naïve and memory $\mathrm{T}$ cells and increases the secretion of Th1 cytokines, but suppresses the production of Th2 cytokines (37). Subsequently, it has been reported that leptin

TABLE 1 | The effects of adipokines on T lymphocytes.

\begin{tabular}{|c|c|c|c|c|c|c|c|}
\hline Adipokines & Naïve $\mathrm{CD}^{+} \mathrm{T}$ & Th1 & Th2 & Th17 & Treg & Tfh & $\mathrm{CD8}^{+} \mathrm{T}$ \\
\hline Leptin & Proliferation $\uparrow$ & $\begin{array}{l}\text { Differentiation } \uparrow \\
\text { Cytokines } \\
\text { secretion } \uparrow\end{array}$ & $\begin{array}{l}\text { Differentiation } \downarrow \\
\text { Cytokines } \\
\text { secretion } \downarrow\end{array}$ & $\begin{array}{l}\text { Differentiation } \uparrow \\
\text { Cytokines } \\
\text { secretion } \uparrow\end{array}$ & Differentiation $\downarrow$ & $\begin{array}{l}\text { Differentiation } \uparrow \\
\text { Cytokines secretion } \uparrow\end{array}$ & Activation $\uparrow$ \\
\hline Adiponectin & $\begin{array}{l}\text { Proliferation } \downarrow \\
\text { Apoptosis } \uparrow\end{array}$ & $\begin{array}{l}\text { Differentiation } \uparrow \downarrow \\
\text { Cytokines } \\
\text { secretion } \uparrow \downarrow\end{array}$ & $\begin{array}{l}\text { Differentiation } \uparrow \\
\text { Cytokines } \\
\text { secretion } \uparrow\end{array}$ & $\begin{array}{l}\text { Differentiation } \uparrow \downarrow \\
\text { Cytokines } \\
\text { secretion } \uparrow \downarrow\end{array}$ & Differentiation $\uparrow$ & Activation $\uparrow$ & Development $\uparrow$ \\
\hline IL-6 & $\begin{array}{l}\text { Proliferation } \uparrow \\
\text { Apoptosis } \downarrow\end{array}$ & $\begin{array}{l}\text { Differentiation } \downarrow \\
\text { Cytokines } \\
\text { secretion } \downarrow\end{array}$ & $\begin{array}{l}\text { Differentiation } \uparrow \\
\text { Cytokines } \\
\text { secretion } \uparrow\end{array}$ & $\begin{array}{l}\text { Differentiation } \uparrow \\
\text { Cytokines } \\
\text { secretion } \uparrow\end{array}$ & Differentiation $\downarrow$ & Differentiation $\uparrow$ & $\begin{array}{l}\text { Differentiation } \uparrow \\
\text { Activation } \uparrow\end{array}$ \\
\hline $\mathrm{TNF}-\alpha$ & Proliferation $\uparrow$ & $\begin{array}{l}\text { Differentiation } \uparrow \\
\text { Cytokines } \\
\text { secretion } \uparrow \\
\text { Migration } \uparrow\end{array}$ & $\begin{array}{l}\text { Differentiation } \downarrow \\
\text { Cytokines } \\
\text { secretion } \downarrow\end{array}$ & $\begin{array}{l}\text { Differentiation } \uparrow \\
\text { Cytokines } \\
\text { secretion } \uparrow \\
\text { Migration } \uparrow\end{array}$ & Differentiation $\downarrow$ & - & $\begin{array}{l}\text { Activation } \uparrow \\
\text { Proliferation } \uparrow \\
\text { Migration } \uparrow\end{array}$ \\
\hline Resistin & Migration $\uparrow$ & - & - & - & Differentiation $\uparrow$ & - & - \\
\hline Visfatin & Activation $\uparrow$ & - & - & - & - & - & - \\
\hline
\end{tabular}

$\uparrow$ Indicates upregulation, $\downarrow$ indicates downregulation, $\uparrow \downarrow$ indicates both upregulation and downregulation, - indicates unknown. 
constrains the activation and proliferation of Treg cells (38). Mechanism studies have shown that leptin activates the mTOR pathway, thereby exerting a positive effect on $\mathrm{CD} 4^{+} \mathrm{CD} 25^{-}$ FOXP3 ${ }^{-}$effector T cells (Teffs), but inhibiting Foxp3 expression and the proliferation of Treg cells $(39,40)$. Leptin also promotes Th17 responses by inducing the transcription of retinoid-related orphan receptor $\gamma \mathrm{t}(\mathrm{ROR} \gamma \mathrm{t})$, the key transcription factor for Th17 differentiation (41). In addition, leptin has positive effects on the generation, maturation and survival of thymic $\mathrm{T}$ cells by reducing their apoptosis (42). Furthermore, leptin increases the secretion of inflammatory cytokines (e.g. IL-6, IL-12 and TNF- $\alpha$ ) as well as the expression of chemokine ligands (e.g. CCL3, CCL4 and CCL5) by activating the JAK2-STAT3 pathway in monocytes/ macrophages from human or mice $(43,44)$, thereby indirectly promoting differentiation and adaptive immune response of T cells.

Due to its strong effects on T cells, leptin participates in the pathological processes of a variety of inflammatory and autoimmune diseases. In obesity-induced adipose inflammation, leptin stimulates IFN- $\gamma$ secretion from ART, which leads to an increase in pro-inflammatory Th1 cells and a decrease in anti-inflammatory Tregs in adipose tissue (8). Leptin gene expression in adipocytes is elevated within 1 week of HFD, suggesting that leptin plays a role in initiating the cascade of adipose inflammation. Moreover, because leptin can promote the proliferation of autoreactive $\mathrm{T}$ cells and differentiation of pro-inflammatory Th1 and Th17 cells in human and mice, it has been reported to be involved in the induction and progression of $\operatorname{IBD}(45,46)$, multiple sclerosis (47-49), rheumatoid arthritis $(50,51)$ and systemic lupus erythematosus $(41,52)$

\section{Adiponectin}

Adiponectin has dual effects on $\mathrm{T}$ cell function. Several studies have shown that adiponectin is a negative regulator of $\mathrm{T}$ cell activity. It has been reported that adiponectin inhibits the proliferation and cytokine production of $\mathrm{T}$ cells, and promotes their apoptosis (53). Recent data indicates that adiponectin inhibits Th1 and Th17 differentiation through the upregulation of SIRT1 and PPAR $\gamma$ and inhibition of ROR $\gamma$ t (54). It also suppresses IL-17 production from $\gamma \delta$-T cells (55). Therefore, adiponectin ameliorates Th17 cell-mediated autoimmune diseases, including experimental autoimmune encephalomyelitis (EAE) (54) and psoriasiform skin inflammation (55). In a mouse model of abortion, adiponectin increases Treg cell population via enhancing Foxp3 expression, thereby improving the pregnancy rate of this model (56). Furthermore, the immunomodulatory effect of adiponectin on $\mathrm{T}$ cells is partially mediated by its ability to suppress the allostimulatory capacity of dendritic cells (DCs) (57). Adiponectin suppresses the expression of MHCII and costimulators CD80 and CD86, and induces the expression of coinhibitor PD-L1 in DCs. Adiponectin-treated DCs show a reduced capacity to promote $\mathrm{CD} 4^{+} \mathrm{T}$ cell proliferation and an enhanced capacity to induce Treg expansion in DC-T cell cocultures (57).

However, some studies showed opposite results that adiponectin is a pro-inflammatory adipokine. In human polyclonally activated $\mathrm{CD}^{+} \mathrm{T}$ cells, adiponectin treatment results in the increased secretion of IFN- $\gamma$ and IL-6, phosphorylation of p38 MAPK and STAT4 and expression of T-bet, which indicates a potential function of adiponectin promoting Th1 differentiation (58). Moreover, adiponectin aggravates collagen-induced arthritis (CIA) via enhancing Th17 cells and $\mathrm{T}$ follicular helper (Tfh) cells response (59). Adiponectin also reduces the apoptosis of lamina propria $\mathrm{T}$ lymphocytes (LPL-T) in IBD patients by inducing expression of anti-apoptotic proteins $\mathrm{Bcl}-\mathrm{xL}$ and $\mathrm{Bcl}-2$, leading to $\mathrm{T}$ cellmediated inflammation (46). Adiponectin also indirectly promotes Th1 and Th17 polarization by activating DCs through PLC $\gamma / J N K / N F-\kappa B$ signaling pathway (60).

The reason for the discrepancy in effects of adiponectin on $\mathrm{T}$ cells is unclear. Adiponectin circulating in plasma has three major forms: trimer, hexamer, and high molecular weight (HMW) multimer (61). Different oligomers activate different intracellular signaling pathways, resulting in significantly different effects (62). It is possible that different oligomers of adiponectin were used in different studies, which results in this discrepancy.

\section{IL-6}

IL-6 is a pro-inflammatory cytokine that is secreted by various immune cells. Adipocytes also express IL-6. Although adipocytes are not the main source of IL-6 in adipose tissue, IL- 6 has been considered as an adipokine (63). IL- 6 has different effects on different $\mathrm{CD}^{+} \mathrm{T}$ cell subsets. It was reported that IL- 6 inhibits Th1 differentiation by upregulating the expression of a suppressor of cytokine signaling,(SOCS)-1, a potent inhibitor of IFN- $\gamma$ signaling (64). IL-6 also inhibits TGF- $\beta$-induced Treg cell's differentiation $(65,66)$. However, IL-6 induces the production of IL-4, resulting in increased Th2 polarization (67). In addition, IL-6 is a crucial cytokine for lineage commitment to Th17 cells. IL-6 promotes Th17 differentiation by activating STAT3, which upregulates the expression of ROR $\gamma t$ and $\operatorname{ROR} \alpha(68,69)$. Furthermore, IL-6 is a positive regulator of Tfh cells (70), which is supported by the observation that the early differentiation of Tfh cells is severely impaired in IL-6 deficient mice (71).

Although the regulatory effect of IL- 6 on $\mathrm{CD} 4^{+} \mathrm{T}$ cells has been extensively studied, the effect of IL- 6 on $\mathrm{CD}^{+} \mathrm{T}$ cells is still poorly understood. IL- 6 may positively regulate $\mathrm{CD}^{+} \mathrm{T}$ cell function. IL- 6 was found to promote the generation of $\mathrm{CD}^{+}$ cytotoxic $\mathrm{T}$ cells (72). It was reported that IL-6 induces the differentiation of naïve $\mathrm{CD}^{+} \mathrm{T}$ cells into IL-21-producing $\mathrm{CD} 8^{+}$ $\mathrm{T}$ cells, which improve IgG isotype switching in B cells during influenza virus infection (73). This is a new function for IL-6 in the prevention of viral infection. Furthermore, IL- 6 promotes the differentiation of IL-22-producing $\mathrm{CD}^{+} \mathrm{T}$ cells, a $\mathrm{CD}^{+} \mathrm{T}$ cell subset with antitumor function (74).

\section{Other Adipokines}

In addition to the adipokines mentioned above, some other secreting factors of adipocytes, including resistin, visfatin, and TNF- $\alpha$, also regulate T cell function. Resistin induces activation of Src and PI3K in human $\mathrm{CD}^{+}{ }^{+} \mathrm{T}$ lymphocytes and serves as a 
chemokine for these cells (75). Moreover, resistin indirectly enhances Treg expansion through the regulation of DCs, in which interferon regulatory factor (IRF)-1 pathway is suppressed by resistin (76). Visfatin is an adipokine that upregulates the activation of $\mathrm{T}$ cells. It promotes the production of IL-1 $\beta$, IL-1Ra, IL- 6 , IL-10, and TNF- $\alpha$ and the expression of costimulatory molecules CD80, CD40 and ICAM-1 (CD54) in monocytes, thereby stimulating the activation of T cells (77). It is worthy to note that although visfatin is expressed in adipose tissue, its expression is higher in bone marrow, the liver and muscles (78). Additionally, in the adipose tissue, visfatin is not only expressed in adipocytes. Studies have found that visfatin is mainly produced and released by macrophages in white adipose tissues (79). Therefore, adipocytes may not be the major source of visfatin expression. TNF- $\alpha$ is an important immunomodulatory cytokine, which plays a critical role in regulating the proliferation, differentiation, and apoptosis of $\mathrm{T}$ cells, the generation of memory $\mathrm{T}$ cells, and maintenance of immune tolerance (80). It has been reported that TNF- $\alpha$ is secreted by adipocytes and other immune cells $(81,82)$. However, whether adipocytes produce TNF- $\alpha$ is still controversial.

\section{THE ROLE OF ADIPOCYTES IN B CELL- MEDIATED ADAPTIVE IMMUNITY}

Similar to $\mathrm{T}$ cell activation and differentiation, B cell activation and differentiation also requires three signals. But unlike $\mathrm{T}$ cells that recognize antigens presented by APCs, B cells recognize free antigens through B cell receptor (BCR). B cells specifically recognize antigens through $B C R$, generating the first signal for B cell activation. B cells are per se professional APCs. B cells internalize the antigen bound by BCR and process the antigen to form an antigen peptide-MHCII complex, which is presented to antigen-specific Th cells. After Th cells are activated, they express high levels of co-stimulatory molecules and combine with matched ligands or receptors on the surface of B cells, which provides the second signal for B cell activation. Activated B cells express multiple cytokine receptors, and proliferate and differentiate into antibody-forming cells under the action of cytokines that are secreted by activated $\mathrm{T}$ cells or other cells. For B cell activation, the role that adipocyte plays on the two key signals, antigen recognition and costimulation has not yet been reported, but some studies have reported that several adipokines play a role in the development and differentiation of B cells. Here we discuss the role that adipocytes play in regulating $\mathrm{B}$ cellmediated adaptive immune responses through secreted cytokines (Table 2).

\section{Leptin}

In addition to regulating $\mathrm{T}$ lymphocytes mediated immune responses, leptin plays an important role in the regulation of $\mathrm{B}$ cell development and function. Deficiency of leptin signaling in $\mathrm{ob} / \mathrm{ob}$ and $\mathrm{db} / \mathrm{db}$ mice leads to the decrease of $\mathrm{B}$ cells in bone marrow and peripheral blood, while intraperitoneal injection of leptin in ob/ob mice restores the number of bone marrow B cells (83), suggesting that leptin plays a critical role in supporting B cell development. Fasted mice, characterized by low serum leptin levels, show decreased pro-B and immature B cells and increased mature B cells in bone marrow (84). Leptin receptor is expressed on B cells, suggesting a direct effect of leptin on B cells (85). However, the fasting-induced atrophy of bone marrow B cells is reversed by intracerebroventricular leptin injection, indicating that leptin may indirectly regulate B cell development through the central nervous system (86). In addition to its effects on the regulation of B cell development, leptin suppresses apoptosis and induces cell cycle entry of B cells by upregulating the expression of Bcl-2 and Cyclin D1 (87). Moreover, leptin stimulates human $B$ cells to secrete proinflammatory (TNF- $\alpha$ and IL-6) and antiinflammatory (IL-10) cytokines, via activation of JAK2/STAT3 and p38MAPK/ERK1/2 signaling pathway (88). Interestingly, leptin-induced production of TNF- $\alpha$, IL- 6 and IL-10 in B cells from aged individuals are significantly higher than that in B cells from young individuals (89). Furthermore, leptin promotes immunosenescence of human B cells. Leptin treatment results in declined immunoglobulin class switch and influenza vaccinespecific IgG production in human B cells (90).

\section{Adiponectin}

Adiponectin has two receptors, ADIPOR1 and ADIPOR2. Both are abundantly expressed on the surface of circulating B cells (91).

TABLE 2 | The effects of adipokines on B lymphocytes.

\begin{tabular}{|c|c|c|c|c|c|}
\hline Adipokines & Pro-B & Pre-B & Immature B & Mature B & Plasma B \\
\hline Leptin & Development $\uparrow$ & Development $\uparrow$ & Development $\uparrow$ & $\begin{array}{l}\text { Development } \downarrow \\
\text { Cytokines secretion } \uparrow\end{array}$ & Antibody production $\uparrow$ \\
\hline Adiponectin & Development $\downarrow$ & Development $\downarrow$ & - & Cytokines secretion $\uparrow$ & - \\
\hline IL-6 & - & - & - & $\begin{array}{l}\text { Differentiation } \uparrow \\
\text { Proliferation } \uparrow\end{array}$ & Antibody production $\uparrow$ \\
\hline Visfatin & - & Colony formation $\uparrow$ & - & $\begin{array}{l}\text { Activation } \uparrow \\
\text { Migration } \uparrow\end{array}$ & - \\
\hline BAFF & - & - & - & $\begin{array}{l}\text { Survival } \uparrow \\
\text { Maturation } \uparrow \\
\text { Proliferation } \uparrow\end{array}$ & Antibody production $\uparrow$ \\
\hline Other soluble factors & Development $\downarrow$ & Development $\downarrow$ & - & - & - \\
\hline
\end{tabular}

$\uparrow$ Indicates upregulation, $\downarrow$ indicates downregulation, - indicates unknown. 
However, the immunomodulatory effects of adiponectin on B lymphocytes are not very clear. It has been reported that adiponectin inhibits B lymphopoiesis in long-term bone marrow cultures. This effect is highly dependent on the presence of both stromal cells and early B lineage precursors in the cultures (92). Adiponectin deficient mice treated with dextran sulfate sodium (DSS) present more significant B cells infiltration in colons and appear more severe colitis than WT littermates, indicating that adiponectin may suppress B cell-mediated inflammatory response in DSS-induced colitis (93). Moreover, adiponectin stimulates B cells to secret a peptide, PEPITEM, which specifically inhibits the migration of $\mathrm{CD} 4^{+}$and $\mathrm{CD} 8{ }^{+}$memory T cells (94). Further studies are guaranteed to address the detailed role of adiponectin in regulating B lymphocytes function.

\section{Other Adipokines}

Leptin and adiponectin are exclusively expressed in adipocyte. Some other adipokines that are secreted by both adipocytes and other types of cells also have regulatory effects on B cells. These adipokines include visfatin, B cell activation factor (BAFF), and IL-6. Visfatin was previously called 'pre-B cell colony-enhancing factor (PBEF)', since it enhances pre-B-cell colony formation in the presence of both IL-7 and SCF (78). Visfatin is a potent chemotactic factor for $\mathrm{B}$ cells and promotes $\mathrm{B}$ cell migration in vitro cell culture (77). BAFF, also known as 'B lymphocyte stimulator (BlyS)', promotes B cell proliferation, survival, maturation and immunoglobulin secretion $(95,96)$. The production of BAFF is upregulated in obese human adipocyte, and it may activate B cells in adipose tissue during obesity (97). IL-6 was originally named 'B-cell stimulatory factor 2 (BSF-2)'. This name reflects its function to induce differentiation of activated B cells into antibody (Ab)-producing cells (98). IL-6 is abundantly secreted by adipocytes during obesity, and aggravates obesity-induced insulin resistance (99). In addition, some unidentified soluble factors secreted by adipocytes inhibit B lymphopoiesis $(100,101)$. These factors may mediate the decline of B lymphopoiesis in aged and obese individuals, and both conditions are characterized by increased fat accumulation in bone marrow.

\section{CONCLUSION AND FUTURE DIRECTIONS}

Recently, the immunological function of adipocytes has received increasing attention. Mounting evidence indicates that adipocytes play an important role in adaptive immunity (Figure 1). Adipocytes can serve as APCs to regulate T cellmediated adaptive immunity. The MHCII molecules are expressed in adipocytes and their expressions are upregulated during obesity, providing the first signal for $\mathrm{CD}^{+} \mathrm{T}$ cell activation. Simultaneously, adipocytes of obese mice and humans overexpress several costimulatory molecules, including CD40, CD80 (B7-1), CD86 (B7-2) and HVEM. Those constimulators are associated with obesity-induced adipose inflammation and metabolic disorders. However, studies exhibited conflicting results and did not provide convincing data from adipocyte-specific knockout mouse models. Therefore, it is too early to draw a conclusion that adipocytes provide the key costimulatory signal for ART activation. In addition, adipocytes secrete various cytokines, such as leptin, adiponectin, IL- 6 , resistin, visfatin and TNF- $\alpha$, which regulate the proliferation and differentiation of $\mathrm{T}$ cells and are involved in many chronic inflammatory and autoimmune diseases. In B cellmediated humoral immunity, adipocytes regulate $B$ cell development, proliferation, differentiation, activation and antibody production through secreted adipokines.

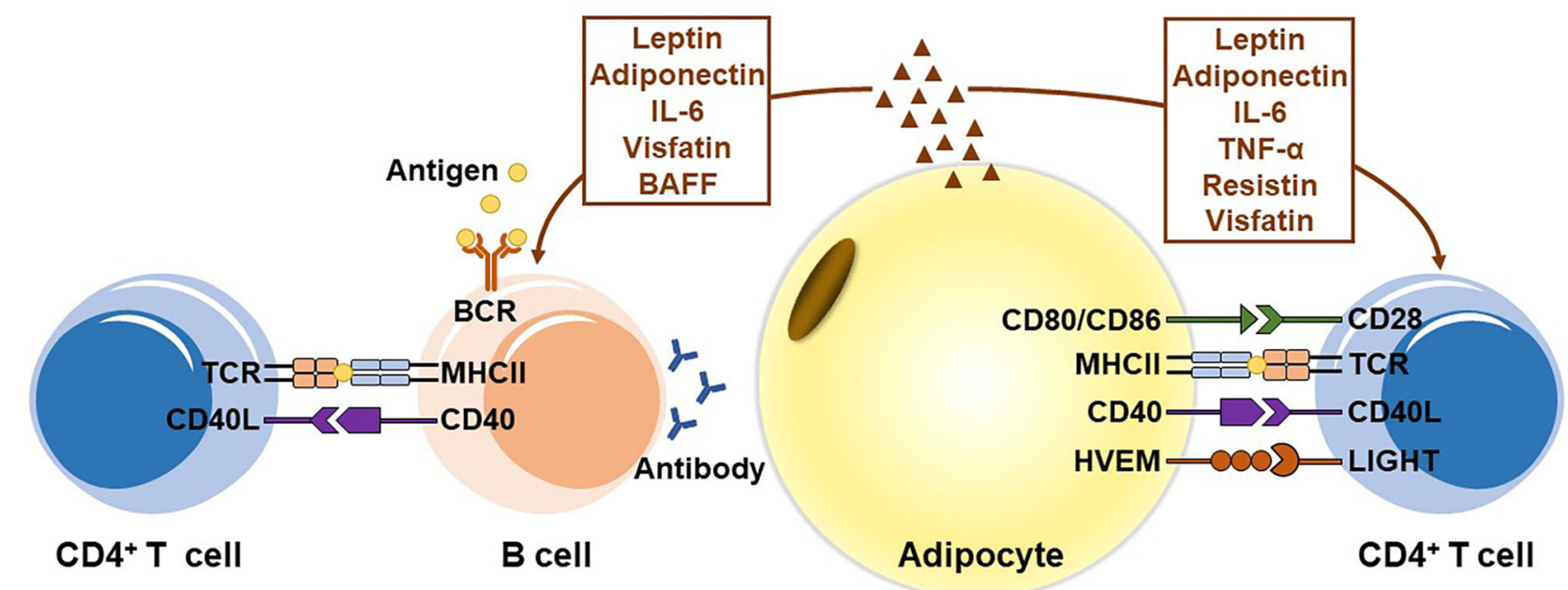

FIGURE 1 | The role of adipocytes in adaptive immunity. Adipocytes express MHC class II molecules and several T cell costimulators to act as antigen-presenting cells (APCs), and induce the activation of $\mathrm{CD}^{+} \mathrm{T}$ cells in visceral adipose tissue during obesity. In addition, adipocytes secrete various adipokines, including leptin, adiponectin, IL-6, TNF- $\alpha$, resistin, and visfatin, to regulate the proliferation and differentiation of T cells. In B cell-mediated humoral immunity, adipocytes modulate B cell generation, development, aging, activation and antibody production mainly by secreting adipokines, including leptin, adiponectin, IL-6, visfatin, and BAFF. 
In the past few years, although great progress has been made in understanding the mechanism and function of adipocytes in adaptive immunity, there are still many imperative questions remaining to be answered in this emerging field. Many studies have implied the existence of specific antigens to activate $\mathrm{T}$ cells in adipose tissue, but up until now, no any adipose antigen has been reported. In addition, although many $\mathrm{T}$ cell costimulators have been linked to obesity-induced adipose inflammation and insulin resistance, the key co-stimulator(s) in obesity-induced ART activation are not known. Identifying of antigen(s) which are recognized by ART in obesity and the key co-stimulatory signaling in ART activation may provide new targets for specifically block obesity-induced adipose inflammation. We found that obesity induces MHCII expression in adipocytes and causes adipocytes to become APCs. But it is still unclear whether all adipocytes or just a subset of adipocytes are converted to APC in obesity. If the latter is true, further studies are warranted to investigate the origin and features of this special adipocyte subpopulation. Finally, compared with the number of studies which concern adipocytes regulating the function of $\mathrm{T}$ cells, there are far fewer studies on adipocytes

\section{REFERENCES}

1. Bonilla FA, Oettgen HC. Adaptive immunity. J Allergy Clin Immunol (2010) 125:S33-40. doi: 10.1016/j.jaci.2009.09.017

2. Ouchi N, Parker JL, Lugus JJ, Walsh K. Adipokines in inflammation and metabolic disease. Nat Rev Immunol (2011) 11:85-97. doi: 10.1038/nri2921

3. Deng T, Lyon CJ, Bergin S, Caligiuri MA, Hsueh WA. Obesity, Inflammation, and Cancer. Annu Rev Pathol: Mech Dis (2016) 11:421-49. doi: 10.1146/annurev-pathol-012615-044359

4. Rosen ED, Spiegelman BM. What we talk about when we talk about fat. Cell (2014) 156:20-44. doi: 10.1016/j.cell.2013.12.012

5. Huh JY, Kim JI, Park YJ, Hwang IJ, Lee YS, Sohn JH, et al. A novel function of adipocytes in lipid antigen presentation to iNKT cells. Mol Cell Biol (2013) 33:328-39. doi: 10.1128/MCB.00552-12

6. Satoh M, Hoshino M, Fujita K, Iizuka M, Fujii S, Clingan CS, et al. Adipocyte-specific CD1d-deficiency mitigates diet-induced obesity and insulin resistance in mice. Sci Rep (2016) 6:28473. doi: 10.1038/srep28473

7. Schipper HS, Rakhshandehroo M., van de Graaf SF, Venken K, Koppen A, Stienstra R, et al. Natural killer $\mathrm{T}$ cells in adipose tissue prevent insulin resistance. J Clin Invest (2012) 122:3343-54. doi: 10.1172/JCI62739

8. Deng T, Lyon CJ, Minze LJ, Lin J, Zou J, Liu JZ, et al. Class II Major Histocompatibility Complex Plays an Essential Role in Obesity-Induced Adipose Inflammation. Cell Metab (2013) 17:411-22. doi: 10.1016/ j.cmet.2013.02.009

9. McLaughlin T, Ackerman SE, Shen L, Engleman E. Role of innate and adaptive immunity in obesity-associated metabolic disease. J Clin Invest (2017) 127:5-13. doi: 10.1172/JCI88876

10. Zhou T, Hu Z, Yang S, Sun L, Yu Z, Wang G, et al. Role of Adaptive and Innate Immunity in Type 2 Diabetes Mellitus. J Diabetes Res (2018) 2018:7457269. doi: 10.1155/2018/7457269

11. Chng MH, Alonso MN, Barnes SE, Nguyen KD, Engleman EG. Adaptive Immunity and Antigen-Specific Activation in Obesity-Associated Insulin Resistance. Mediators Inflammation (2015) 2015:593075. doi: 10.1155/2015/ 593075

12. Ting JP, Trowsdale J. Genetic control of MHC class II expression. Cell (2002) 109:S21-33. doi: 10.1016/s0092-8674(02)00696-7

13. Xiao L, Yang X, Lin Y, Li S, Jiang J, Qian S, et al. Large adipocytes function as antigen-presenting cells to activate CD4(+) T cells via upregulating MHCII in obesity. Int J Obes (Lond) (2016) 40:112-20. doi: 10.1038/ijo.2015.145 regulating the function of B cells. Except for adipokines, we know little about how adipocytes regulate the $\mathrm{B}$ cell-mediated adaptive immune response. Future studies on the mechanisms by which adipocytes regulate $B$ cell function will help us better understand the physiological and pathological functions of adipocytes in $\mathrm{B}$ cell-mediated humoral immunity.

\section{AUTHOR CONTRIBUTIONS}

JS and TD wrote and revised the manuscript. All authors contributed to the article and approved the submitted version.

\section{FUNDING}

This work was supported by grants from the National Natural Science Foundation of China (81770868), the Major Research plan of the National Natural Science Foundation of China (91742103), and the Project of Innovation-Driven Plan of Central South University (2020CX015).

14. Deng T, Liu J, Deng Y, Minze L, Xiao X, Wright V, et al. Adipocyte adaptive immunity mediates diet-induced adipose inflammation and insulin resistance by decreasing adipose Treg cells. Nat Commun (2017) 8:2-7 doi: $10.1038 /$ ncomms 15725

15. Feuerer M, Herrero L, Cipolletta D, Naaz A, Wong J, Nayer A, et al. Lean, but not obese, fat is enriched for a unique population of regulatory $\mathrm{T}$ cells that affect metabolic parameters. Nat Med (2009) 15:930-9. doi: 10.1038/ nm.2002

16. Ilan Y, Maron R, Tukpah AM, Maioli TU, Murugaiyan G, Yang K, et al Induction of regulatory $\mathrm{T}$ cells decreases adipose inflammation and alleviates insulin resistance in ob/ob mice. Proc Natl Acad Sci USA (2010) 107:976570. doi: 10.1073/pnas.0908771107

17. Deiuliis J, Shah Z, Shah N, Needleman B, Mikami D, Narula V, et al. Viscera adipose inflammation in obesity is associated with critical alterations in tregulatory cell numbers. PloS One (2011) 6:e16376. doi: 10.1371/ journal.pone.0016376

18. Zhang SY, Lv Y, Zhang H, Gao S, Wang T, Feng J, et al. Adrenomedullin 2 Improves Early Obesity-Induced Adipose Insulin Resistance by Inhibiting the Class II MHC in Adipocytes. Diabetes (2016) 65:2342-55. doi: 10.2337/ db15-1626

19. Lee YS, Kim JW, Osborne O, Oh DY, Sasik R, Schenk S, et al. Increased adipocyte O2 consumption triggers HIF-1alpha, causing inflammation and insulin resistance in obesity. Cell (2014) 157:1339-52. doi: 10.1016/j.cell.2014.05.012

20. Chen L, Flies DB. Molecular mechanisms of T cell co-stimulation and coinhibition. Nat Rev Immunol (2013) 13:227-42. doi: 10.1038/nri3405

21. Seijkens T, Kusters P, Chatzigeorgiou A, Chavakis T, Lutgens E. Immune cell crosstalk in obesity: a key role for costimulation? Diabetes (2014) 63:398291. doi: $10.2337 / \mathrm{db} 14-0272$

22. Poggi M, Jager J, Paulmyer-Lacroix O, Peiretti F, Gremeaux T, Verdier M., et al. The inflammatory receptor CD40 is expressed on human adipocytes: contribution to crosstalk between lymphocytes and adipocytes. Diabetologia (2009) 52:1152-63. doi: 10.1007/s00125-009-1267-1

23. Chatzigeorgiou A, Chung KJ, Garcia-Martin R, Alexaki VI, Klotzsche-von Ameln A, Phieler J, et al. Dual role of B7 costimulation in obesity-related nonalcoholic steatohepatitis and metabolic dysregulation. Hepatology (2014) 60:1196-210. doi: 10.1002/hep.27233

24. Kim HM, Jeong CS, Choi HS, Kawada T, Yu R. LIGHT/TNFSF14 enhances adipose tissue inflammatory responses through its interaction with HVEM. FEBS Lett (2011) 585:579-84. doi: 10.1016/j.febslet.2011.01.011 
25. Bassols J, Moreno JM, Ortega F, Ricart W, Fernandez-Real JM. Characterization of herpes virus entry mediator as a factor linked to obesity. Obes (Silver Spring) (2010) 18:239-46. doi: 10.1038/oby.2009.250

26. Engel D, Seijkens T, Poggi M, Sanati M, Thevissen L, Beckers L, et al. The immunobiology of CD154-CD40-TRAF interactions in atherosclerosis. Semin Immunol (2009) 21:308-12. doi: 10.1016/j.smim.2009.06.004

27. Chatzigeorgiou A, Seijkens T, Zarzycka B, Engel D, Poggi M, van den Berg S, et al. Blocking CD40-TRAF6 signaling is a therapeutic target in obesityassociated insulin resistance. Proc Natl Acad Sci USA (2014) 111:2686-91. doi: 10.1073/pnas.1400419111

28. Rudd CE, Taylor A, Schneider H. CD28 and CTLA-4 coreceptor expression and signal transduction. Immunol Rev (2009) 229:12-26. doi: 10.1111/ j.1600-065X.2009.00770.x

29. del Rio ML, Lucas CL, Buhler L, Rayat G, Rodriguez-Barbosa JII. HVEM/ LIGHT/BTLA/CD160 cosignaling pathways as targets for immune regulation. J Leukoc Biol (2010) 87:223-35. doi: 10.1189/jlb.0809590

30. Bassols J, Moreno-Navarrete JM, Ortega F, Ricart W, Fernandez-Real JM. LIGHT is associated with hypertriglyceridemia in obese subjects and increased cytokine secretion from cultured human adipocytes. Int $J$ Obes (Lond) (2010) 34:146-56. doi: 10.1038/ijo.2009.199

31. Cheung TC, Steinberg MW, Oborne LM, Macauley MG, Fukuyama S, Sanjo $\mathrm{H}$, et al. Unconventional ligand activation of herpesvirus entry mediator signals cell survival. Proc Natl Acad Sci USA (2009) 106:6244-9. doi: 10.1073/pnas.0902115106

32. Kim HJ, Kim HM., Kim CS, Jeong CS, Choi HS, Kawada T, et al. HVEMdeficient mice fed a high-fat diet are protected from adipose tissue inflammation and glucose intolerance. FEBS Lett (2011) 585:2285-90. doi: 10.1016/j.febslet.2011.05.057

33. Tilg H, Moschen AR. Adipocytokines: mediators linking adipose tissue, inflammation and immunity. Nat Rev Immunol (2006) 6:772-83. doi: $10.1038 /$ nri1937

34. Hotamisligil GS. Inflammation and metabolic disorders. Nature (2006) 444:860-7. doi: 10.1038/nature05485

35. Saltiel AR, Olefsky JM. Inflammatory mechanisms linking obesity and metabolic disease. J Clin Invest (2017) 127:1-4. doi: 10.1172/JCI92035

36. Fasshauer M, Bluher M. Adipokines in health and disease. Trends Pharmacol Sci (2015) 36:461-70. doi: 10.1016/j.tips.2015.04.014

37. Lord GM, Matarese G, Howard JK, Baker RJ, Bloom SR, Lechler RI, et al. Leptin modulates the $\mathrm{T}$-cell immune response and reverses starvationinduced immunosuppression. Nature (1998) 394:897-901. doi: 10.1038/ 29795

38. De Rosa V, Procaccini C, Calì G, Pirozzi G, Fontana S, Zappacosta S, et al. A key role of leptin in the control of regulatory $\mathrm{T}$ cell proliferation. Immunity (2007) 26:241-55. doi: 10.1016/j.immuni.2007.01.011

39. Procaccini C, De Rosa V, Galgani M, Carbone F, Cassano S., Greco D., et al. Leptin-induced mTOR activation defines a specific molecular and transcriptional signature controlling CD4+ effector $\mathrm{T}$ cell responses. J Immunol (2012) 189:2941-53. doi: 10.4049/jimmunol.1200935

40. Procaccini C, Galgani M, De Rosa V, Matarese G. Intracellular metabolic pathways control immune tolerance. Trends Immunol (2012) 33:1-7. doi: 10.1016/j.it.2011.09.002

41. Yu Y, Liu Y, Shi FD, Zou H, Matarese G, La Cava A, et al. Cutting edge: Leptin-induced RORgammat expression in CD4+ T cells promotes Th17 responses in systemic lupus erythematosus. J Immunol (2013) 190:3054-8. doi: 10.4049/jimmunol.1203275

42. Howard JK, Lord GM, Matarese G, Vendetti S, Ghatei MA, Ritter MA, et al. Leptin protects mice from starvation-induced lymphoid atrophy and increases thymic cellularity in ob/ob mice. J Clin Invest (1999) 104:10519. doi: $10.1172 /$ JCI6762

43. Kiguchi N, Maeda T, Kobayashi Y, Fukazawa Y, Kishioka S. Leptin enhances CC-chemokine ligand expression in cultured murine macrophage. Biochem Biophys Res Commun (2009) 384:311-5. doi: 10.1016/j.bbrc.2009.04.121

44. Santos-Alvarez J, Goberna R, Sanchez-Margalet V. Human leptin stimulates proliferation and activation of human circulating monocytes. Cell Immunol (1999) 194:6-11. doi: 10.1006/cimm.1999.1490

45. Bilski J, Mazur-Bialy A, Wojcik D, Surmiak M, Magierowski M, Sliwowski Z, et al. Role of Obesity, Mesenteric Adipose Tissue, and Adipokines in
Inflammatory Bowel Diseases. Biomolecules (2019) 9:9-10. doi: 10.3390/ biom 9120780

46. Ponemone V, Keshavarzian A, Brand MI, Saclarides T, Abcarian H, Cabay RJ, et al. Apoptosis and inflammation: role of adipokines in inflammatory bowel disease. Clin Transl Gastroenterol (2010) 1:e1. doi: 10.1038/ ctg. 2010.1

47. De Rosa V, Procaccini C, La Cava A, Chieffi P, Nicoletti GF, Fontana S, et al. Leptin neutralization interferes with pathogenic $\mathrm{T}$ cell autoreactivity in autoimmune encephalomyelitis. J Clin Invest (2006) 116:447-55. doi: 10.1172/JCI26523

48. Galgani M, Procaccini C, De Rosa V, Carbone F, Chieffi P, La Cava A, et al. Leptin modulates the survival of autoreactive CD4+ $\mathrm{T}$ cells through the nutrient/energy-sensing mammalian target of rapamycin signaling pathway. J Immunol (2010) 185:7474-9. doi: 10.4049/jimmunol.1001674

49. Ouyang S, Hsuchou H, Kastin AJ, Mishra PK, Wang Y, Pan W, et al. Leukocyte infiltration into spinal cord of EAE mice is attenuated by removal of endothelial leptin signaling. Brain Behav Immun (2014) 40:61-73. doi: 10.1016/j.bbi.2014.02.003

50. Busso N, So A, Chobaz-Péclat V, Morard C, Martinez-Soria E, Talabot-Ayer D., et al. Leptin signaling deficiency impairs humoral and cellular immune responses and attenuates experimental arthritis. J Immunol (2002) 168:87582. doi: 10.4049/jimmunol.168.2.875

51. Fraser DA, Thoen J, Reseland JE, Forre O, Kjeldsen-Kragh J. Decreased CD4+ lymphocyte activation and increased interleukin-4 production in peripheral blood of rheumatoid arthritis patients after acute starvation. Clin Rheumatol (1999) 18:394-401. doi: 10.1007/s100670050125

52. Amarilyo G, Iikuni N, Shi FD, Liu A, Matarese G, La Cava A, et al. Leptin promotes lupus T-cell autoimmunity. Clin Immunol (2013) 149:530-3. doi: 10.1016/j.clim.2013.09.002

53. Wilk S, Scheibenbogen C, Bauer S, Jenke A, Rother M, Guerreiro M, et al. Adiponectin is a negative regulator of antigen-activated $\mathrm{T}$ cells. Eur J Immunol (2011) 41:2323-32. doi: 10.1002/eji.201041349

54. Zhang K, Guo Y, Ge Z, Zhang Z, Da Y, Li W, et al. Adiponectin Suppresses T Helper 17 Cell Differentiation and Limits Autoimmune CNS Inflammation via the SIRT1/PPARgamma/RORgammat Pathway. Mol Neurobiol (2017) 54:4908-20. doi: 10.1007/s12035-016-0036-7

55. Shibata S, Tada Y, Hau CS, Mitsui A, Kamata M, Asano Y, et al. Adiponectin regulates psoriasiform skin inflammation by suppressing IL-17 production from gammadelta-T cells. Nat Commun (2015) 6:7687. doi: 10.1038/ ncomms 8687

56. Li W, Geng L, Liu X, Gui W, Qi H. Recombinant adiponectin alleviates abortion in mice by regulating Th17/Treg imbalance via p38MAPK-STAT5 pathway. Biol Reprod (2019) 100:1008-17. doi: 10.1093/biolre/ioy251

57. Tsang JY, Li D, Ho D, Peng J, Xu A, Lamb J, et al. Novel immunomodulatory effects of adiponectin on dendritic cell functions. Int Immunopharmacol (2011) 11:604-9. doi: 10.1016/j.intimp.2010.11.009

58. Cheng X, Folco EJ, Shimizu K, Libby P. Adiponectin induces proinflammatory programs in human macrophages and CD4+ T cells. J Biol Chem (2012) 287:36896-904. doi: 10.1074/jbc.M112.409516

59. Sun X, Feng X., Tan W, Lin N, Hua M, Wei Y, et al. Adiponectin exacerbates collagen-induced arthritis via enhancing Th17 response and prompting RANKL expression. Sci Rep (2015) 5:11296. doi: 10.1038/srep11296

60. Jung MY, Kim HS, Hong HJ, Youn BS, Kim TS. Adiponectin induces dendritic cell activation via PLCgamma/JNK/NF-kappaB pathways, leading to Th1 and Th17 polarization. J Immunol (2012) 188:2592-601. doi: 10.4049/jimmunol.1102588

61. Fang X, Sweeney G. Mechanisms regulating energy metabolism by adiponectin in obesity and diabetes. Biochem Soc Trans (2006) 34:798801. doi: 10.1042/BST0340798

62. Tsao TS, Tomas E, Murrey HE, Hug C, Lee DH, Ruderman NB, et al. Role of disulfide bonds in Acrp30/adiponectin structure and signaling specificity. Different oligomers activate different signal transduction pathways. J Biol Chem (2003) 278:50810-7. doi: 10.1074/jbc.M309469200

63. Fasshauer M, Klein J, Lossner U, Paschke R. Interleukin (IL)-6 mRNA expression is stimulated by insulin, isoproterenol, tumour necrosis factor alpha, growth hormone, and IL-6 in 3T3-L1 adipocytes. Horm Metab Res (2003) 35:147-52. doi: 10.1055/s-2003-39075 
64. Diehl S, Anguita J, Hoffmeyer A, Zapton T, Ihle JN, Fikrig E, et al. Inhibition of Th1 differentiation by IL-6 is mediated by SOCS1. Immunity (2000) 13:805-15. doi: 10.1016/s1074-7613(00)00078-9

65. Bettelli E, Carrier Y, Gao W, Korn T, Strom TB, Oukka M, et al. Reciprocal developmental pathways for the generation of pathogenic effector TH17 and regulatory T cells. Nature (2006) 441:235-8. doi: 10.1038/nature04753

66. Fujimoto M, Nakano M, Terabe F, Kawahata H, Ohkawara T, Han Y, et al. The influence of excessive IL-6 production in vivo on the development and function of Foxp3+ regulatory T cells. J Immunol (2011) 186:32-40. doi: 10.4049/jimmunol.0903314

67. Rincon M, Anguita J, Nakamura T, Fikrig E, Flavell RA. Interleukin (IL)-6 directs the differentiation of IL-4-producing CD4+ T cells. J Exp Med (1997) 185:461-9. doi: $10.1084 /$ jem.185.3.461

68. Nishihara M, Ogura H, Ueda N, Tsuruoka M, Kitabayashi C, Tsuji F, et al. IL-6-gp130-STAT3 in T cells directs the development of IL-17+ Th with a minimum effect on that of Treg in the steady state. Int Immunol (2007) 19:695-702. doi: 10.1093/intimm/dxm045

69. Yang XO, Pappu BP, Nurieva R, Akimzhanov A, Kang HS, Chung Y, et al. T helper 17 lineage differentiation is programmed by orphan nuclear receptors ROR alpha and ROR gamma. Immunity (2008) 28:29-39. doi: 10.1016/ j.immuni.2007.11.016

70. Crotty S. T follicular helper cell differentiation, function, and roles in disease. Immunity (2014) 41:529-42. doi: 10.1016/j.immuni.2014.10.004

71. Choi YS, Eto D, Yang JA, Lao C, Crotty S. Cutting edge: STAT1 is required for IL-6-mediated Bcl6 induction for early follicular helper cell differentiation. J Immunol (2013) 190:3049-53. doi: 10.4049/jimmunol.1203032

72. Okada M, Kitahara M, Kishimoto S, Matsuda T, Hirano T, Kishimoto T, et al. IL-6/BSF-2 functions as a killer helper factor in the in vitro induction of cytotoxic T cells. J Immunol (1988) 141:1543-9. doi: 10.1016/0192-0561(88) 90486-9

73. Yang R, Masters AR, Fortner KA, Champagne DP, Yanguas-Casás N, Silberger D. J., et al. IL-6 promotes the differentiation of a subset of naive CD8+ T cells into IL-21-producing B helper CD8+ T cells. J Exp Med (2016) 213:2281-91. doi: 10.1084/jem.20160417

74. St Paul M, Saibil SD, Lien SC, Han S, Sayad A, Mulder DT, et al. IL6 Induces an IL22(+) CD8(+) T-cell Subset with Potent Antitumor Function. Cancer Immunol Res (2020) 8:321-33. doi: 10.1158/2326-6066.CIR-19-0521

75. Walcher D, Hess K, Berger R, Aleksic M, Heinz P, Bach H, et al. Resistin: a newly identified chemokine for human CD4-positive lymphocytes. Cardiovasc Res (2010) 85:167-74. doi: 10.1093/cvr/cvp278

76. Son YM, Ahn SM, Kim GR, Moon YS, Kim SH, Park YM, et al. Resistin enhances the expansion of regulatory $\mathrm{T}$ cells through modulation of dendritic cells. BMC Immunol (2010) 11:33. doi: 10.1186/1471-2172-11-33

77. Moschen AR, Kaser A, Enrich B, Mosheimer B, Theurl M, Niederegger H, et al. Visfatin, an adipocytokine with proinflammatory and immunomodulating properties. J Immunol (2007) 178:1748-58. doi: 10.4049/jimmunol.178.3.1748

78. Samal B, Sun Y, Stearns G, Xie C, Suggs S, McNiece I, et al. Cloning and characterization of the cDNA encoding a novel human pre-B-cell colonyenhancing factor. Mol Cell Biol (1994) 14:1431-7. doi: 10.1128/ mcb.14.2.1431

79. Curat CA, Wegner V, Sengenès C, Miranville A, Tonus C., Busse R., et al. Macrophages in human visceral adipose tissue: increased accumulation in obesity and a source of resistin and visfatin. Diabetologia (2006) 49:744-7. doi: 10.1007/s00125-006-0173-z

80. Mehta AK, Gracias DT, Croft M. TNF activity and T cells. Cytokine (2018) 101:14-8. doi: 10.1016/j.cyto.2016.08.003

81. El-Tahan RR, Ghoneim AM, El-Mashad N. TNF-alpha gene polymorphisms and expression. Springerplus (2016) 5:1508. doi: 10.1186/s40064-016-3197-y

82. Hotamisligil GS, Shargill NS, Spiegelman BM. Adipose expression of tumor necrosis factor-alpha: direct role in obesity-linked insulin resistance. Science (1993) 259:87-91. doi: 10.1126/science.7678183

83. Claycombe K, King LE, Fraker PJ. A role for leptin in sustaining lymphopoiesis and myelopoiesis. Proc Natl Acad Sci USA (2008) 105:2017-21. doi: 10.1073/pnas.0712053105

84. Fujita Y, Yanagida H, Mimori T, Jin ZX, Sakai T, Kawanami T, et al. Prevention of fasting-mediated bone marrow atrophy by leptin administration. Cell Immunol (2012) 273:52-8. doi: 10.1016/j.cellimm. 2011.11.007
85. Bennett BD, Solar GP, Yuan JQ, Mathias J, Thomas GR, Matthews W, et al. A role for leptin and its cognate receptor in hematopoiesis. Curr Biol (1996) 6:1170-80. doi: 10.1016/s0960-9822(02)70684-2

86. Tanaka M, Suganami T, Kim-Saijo M, Toda C, Tsuiji M, Ochi K, et al. Role of central leptin signaling in the starvation-induced alteration of B-cell development. J Neurosci (2011) 31:8373-80. doi: 10.1523/JNEUROSCI. 6562-10.2011

87. Lam QL, Wang S, Ko OK, Kincade PW, Lu L. Leptin signaling maintains Bcell homeostasis via induction of Bcl-2 and Cyclin D1. Proc Natl Acad Sci USA (2010) 107:13812-7. doi: 10.1073/pnas.1004185107

88. Agrawal S, Gollapudi S, Su H, Gupta S. Leptin activates human B cells to secrete TNF-alpha, IL-6, and IL-10 via JAK2/STAT3 and p38MAPK/ERK1/ 2 signaling pathway. J Clin Immunol (2011) 31:472-8. doi: 10.1007/s10875010-9507-1

89. Gupta S, Agrawal S, Gollapudi S. Increased activation and cytokine secretion in B cells stimulated with leptin in aged humans. Immun Ageing (2013) 10:3. doi: 10.1186/1742-4933-10-3

90. Frasca D, Diaz A, Romero M, Blomberg BB. Leptin induces immunosenescence in human B cells. Cell Immunol (2020) 348:103994. doi: 10.1016/j.cellimm.2019.103994

91. Pang TT, Narendran P. The distribution of adiponectin receptors on human peripheral blood mononuclear cells. Ann N Y Acad Sci (2008) 1150:143-5. doi: 10.1196/annals.1447.021

92. Yokota T, Meka CS, Kouro T, Medina KL, Igarashi H, Takahashi M, et al. Adiponectin, a fat cell product, influences the earliest lymphocyte precursors in bone marrow cultures by activation of the cyclooxygenase-prostaglandin pathway in stromal cells. J Immunol (2003) 171:5091-9. doi: 10.4049/ jimmunol.171.10.5091

93. Obeid S, Wankell M, Charrez B, Sternberg J, Kreuter R, Esmaili S, et al. Adiponectin confers protection from acute colitis and restricts a $\mathrm{B}$ cell immune response. J Biol Chem (2017) 292:6569-82. doi: 10.1074/jbc.M115.712646

94. Chimen M, McGettrick HM, Apta B, Kuravi SJ, Yates CM, Kennedy A, et al. Homeostatic regulation of $\mathrm{T}$ cell trafficking by a $\mathrm{B}$ cell-derived peptide is impaired in autoimmune and chronic inflammatory disease. Nat Med (2015) 21:467-75. doi: $10.1038 / \mathrm{nm} .3842$

95. Craxton A, Magaletti D, Ryan EJ, Clark EA. Macrophage- and dendritic celldependent regulation of human B-cell proliferation requires the TNF family ligand BAFF. Blood (2003) 101:4464-71. doi: 10.1182/blood-2002-10-3123

96. Mackay F, Woodcock SA, Lawton P, Ambrose C, Baetscher M, Schneider P, et al. Mice transgenic for BAFF develop lymphocytic disorders along with autoimmune manifestations. J Exp Med (1999) 190:1697-710. doi: 10.1084/ jem.190.11.1697

97. Muller N, Schulte DM, Hillebrand S, Türk K, Hampe J, Schafmayer C, et al. B Lymphocyte Stimulator (BLyS) is expressed in human adipocytes in vivo and is related to obesity but not to insulin resistance. PloS One (2014) 9: e94282. doi: 10.1371/journal.pone.0094282

98. Hirano T, Yasukawa K, Harada H, Taga T, Watanabe Y, Matsuda T, et al. Complementary DNA for a novel human interleukin (BSF-2) that induces B lymphocytes to produce immunoglobulin. Nature (1986) 324:73-6. doi: $10.1038 / 324073 \mathrm{a} 0$

99. Allen TL, Febbraio MA. IL6 as a mediator of insulin resistance: fat or fiction? Diabetologia (2010) 53:399-402. doi: 10.1007/s00125-009-1627-x

100. Bilwani FA, Knight KL. Adipocyte-derived soluble factor(s) inhibits early stages of B lymphopoiesis. J Immunol (2012) 189:4379-86. doi: 10.4049/jimmunol.1201176

101. Kennedy DE, Knight KL. Inhibition of B Lymphopoiesis by Adipocytes and IL-1-Producing Myeloid-Derived Suppressor Cells. J Immunol (2015) 195:2666-74. doi: 10.4049/jimmunol.1500957

Conflict of Interest: The authors declare that the research was conducted in the absence of any commercial or financial relationships that could be construed as a potential conflict of interest.

Copyright $\odot 2020$ Song and Deng. This is an open-access article distributed under the terms of the Creative Commons Attribution License (CC BY). The use, distribution or reproduction in other forums is permitted, provided the original author(s) and the copyright owner(s) are credited and that the original publication in this journal is cited, in accordance with accepted academic practice. No use, distribution or reproduction is permitted which does not comply with these terms. 